\title{
THE HONOUR OF THE DEAD - THE MORAL RIGHT OF INTEGRITY POST-MORTEM
}

\author{
Jani McCutcheon*
}

\begin{abstract}
Can the honour of the dead be prejudiced? There is much philosophical debate about whether the dead can, or should, enjoy legal rights. Australia, like many jurisdictions, has apparently bypassed that debate and confers post-mortem moral rights on authors, which endure for at least 70 years after an author's death. The Australian moral right of integrity protects authors from certain conduct in relation to their copyright works, which is prejudicial to their honour or reputation. This deliberate conferral of a posthumous right ostensibly acknowledges that a deceased author's honour can be harmed. This article examines questions surrounding the apparent conundrum of posthumous prejudice to an author's honour. How can prejudice to the honour of the dead be established in the absence of the author, particularly if honour is interpreted subjectively? Do insuperable evidentiary hurdles render the posthumous honour limb of the moral right of integrity illusory? The article concentrates on Australian law, but engages in relevant comparative treatments, particularly with French, Canadian and United Kingdom law. Judicial consideration of moral rights under the common law is scant, particularly in Australia, and rarer still in a post-mortem context. However, the issues explored in the article are important, will inevitably arise for consideration and merit a comprehensive examination.
\end{abstract}

\section{INTRODUCTION}

'Both good and evil are thought to happen to a dead person ...

Take, for example, honours and dishonours.'. ${ }^{1}$

Aristotle recognises that, in general terms, the dead can be dishonoured. Millennia later, it seems the hip-hop group, the Beastie Boys, agree. In December 2013, Goldie Blox, a gender-jamming start up toy manufacturer intent on offering girls more toy choices outside the 'pink aisle' ${ }^{2}$ released a mischievous, tongue-in-cheek promotional video. The advertisement subverted the Beastie Boys' 1986 song 'Girls' ${ }^{3}$ with clever

* Associate Professor, Law School, University of Western Australia.

1 Roger Crisp (ed), Aristotle: Nicomachian Ethics (Cambridge University Press, 2000) 16-7, cited in Kirsten Rabe Smolensky, 'Rights of the Dead' (2009) 37 Hoftsra Law Review 763, 770.

2 Goldie Blox, About Goldie Blox, <http://www.goldieblox.com/pages/about>.

3 The pertinent lyrics are: 'Girls - to do the dishes; Girls - to clean up my room; Girls - to do the laundry'. 
replacement lyrics. ${ }^{4}$ The video soon went viral, receiving more than 8 million hits on YouTube. ${ }^{5}$ It showed three girls eschewing the pink fluff on the TV and building an impressive, complicated 'Rube Goldberg' machine out of everyday items. A copyright stand-off ensued. Was the video a fair use parody, or copyright infringement? Goldie Blox sought a declaration that its use was fair. ${ }^{6}$ The Beastie Boys professed admiration for the Goldie Blox message, ${ }^{7}$ yet pointed out their consistent resistance to the use of their music in advertising, particularly by deceased group member Adam Yauch, whose will clarified that he did not want his music used in advertising. Goldie Blox removed the song from its advertisement, and offered the following explanation in an open letter to the Beastie Boys:

We want you to know that when we posted the video, we were completely unaware that the late, great Adam Yauch had requested in his will that the Beastie Boys songs never be used in advertising. Although we believe our parody video falls under fair use, we would like to respect his wishes and yours. ${ }^{8}$

Thus from a copyright dispute came a moral rights resolution. It was (at least ostensibly) ${ }^{9}$ respect for a dead man's desire to protect the integrity of his music that motivated the capitulation, an ironic position given the lack of moral rights protection for musical or literary works in the United States. ${ }^{10}$

The example highlights the capacity for the moral rights of the dead to influence the conduct of the living. The issue will arise frequently, and is important, given that in most cases, Australian moral rights endure for at least 70 years after the author's death. ${ }^{11}$ Thus in most cases, moral rights are likely to be 'enjoyed' more in death than in life.

Including: 'Girls, you think you know what we want, Girls! Just like the 50s its girls;

Girls build a spaceship

Girls code the new app

Girls that grow up knowing

That they can engineer that'. The original video can still be seen at Katy Waldman, This Awesome Ad, Set to the Beastie Boys, Is How to Get Girls to Become Engineers (19 November 2013) Slate

$<$ www.slate.com/blogs/xx_factor/2013/11/19/goldieblox_commercial_rewrites_the_beas tie_boys_urges_young_girls_to_pursue.html $>$.

5 Victoria Slind-Flor, Goldie Blox Takes Down Parody Video, Will Dismiss Copyright Case (2 December 2013) Bloomberg <http://www.bloomberg.com/news/2013-12-02/fujitsuecosphere-goldieblox-intellectual-property.html>.

6 Goldieblox Inc v Island Def Jam Music Group Case 3:13-cv-05428 (filed 21 November 2013) <http://www.scribd.com/doc/186402972/Beastie>.

7 Dave Itzkoff, Beastie Boys Fight Online Video Parody of "Girls" (25 November 2013) New York Times <http://artsbeat.blogs.nytimes.com/2013/11/25/the-beastie-boys-fight-onlinevideo-parody-of-girls/?smid=tw-share\&_r $=2>$.

8 See Goldie Blox, Our Letter to the Beastie Boys (27 November 2013) <http://blog.goldieblox.com/2013/11/our-letter-to-the-beastie-boys/>.

9 No doubt the fact that Goldie Blox had already received incalculably valuable free publicity, and the legal uncertainty of any fair use contest, were serious factors influencing the capitulation.

10 The only moral rights conferred in the United States are those in respect of visual art. See Visual Artists Rights Act of 1990, 17 USC § 106A (2006 \& Supp 5).

11 Copyright Act 1968 (Cth) ('the Act') s 195AM(2). The exceptions are an author's right of integrity in respect of a film (Copyright Act 1968 (Cth) s 195AM(1)) and performer's right of integrity in respect of a recorded performance (Copyright Act 1968 (Cth) s 195AM(3)), which 
The unique nature of moral rights as personal rights intimately connected to the personality of an author makes their post-mortem application challenging. Numerous legal, practical and policy questions raised by the peculiar character of moral rights affect authors, their legal personal representatives ('LPRs'), users of copyright works, legal advisors, and the judiciary. Those issues, particularly as exacerbated by the considerable temporal reach of post-mortem moral rights into the distant future, remain largely unexplored in common law jurisprudence, are barely addressed under Australian law, and demand closer examination.

This article concentrates on post-mortem issues relating to the exercise of the moral right of integrity, ${ }^{12}$ particularly as it protects posthumous honour. Many unresolved issues concerning this moral right apply to both living and dead authors, such as the meaning and function of 'honour', and the influence of the author's subjective responses to the impugned act. However, some issues, particularly evidentiary issues, are intensified post-mortem, and these are explored in the article. Those questions include whether prejudice to authorial honour can occur after the author's death, and how it can be evinced. Do the problems of post-mortem protection mean that deceased authors are effectively discriminated against by reason of their death? The principles developed by future courts will shape the responses to these and other questions. They will illuminate the extent to which deceased authors can inhibit conduct in relation to their works many decades after their death.

The article discusses the particular difficulty of establishing subjective harm in the absence of the subject. While the post-mortem protection of honour is problematic, a flexible evidentiary approach is necessary to fulfil Parliament's objective in conferring post-mortem moral rights which constrain prejudice to honour. A number of evidentiary models are suggested for establishing posthumous harm to honour, and Australian, French, Canadian, and United Kingdom case law is mined for guidance and illustration. Ultimately, a model which elevates the author's work itself to the status of chief witness is advocated as the most flexible, universally applicable model. The article then advocates and considers a number of possible objective controls to ameliorate the risk of a deceased author's subjective honour resulting in overreach from the grave.

\section{A BRIEF OUTLINE OF MORAL RIGHTS AND REMEDIES}

\section{A The rights}

In Australia, authors enjoy three moral rights in respect of their literary, dramatic, musical, and artistic works, films ${ }^{13}$ and performances. ${ }^{14}$ After death, the author's LPR may exercise the moral rights (except the right of integrity in respect of films). ${ }^{15}$

rights cease on the author/performer's death. All further references to sections number are references to the Act unless otherwise stated.

12 The numerous issues that arise in respect of the author's LPR are explored in a separate forthcoming article by the author.

13 In respect of films, the author is defined as the principal director, the principal producer and the principal screenwriter. Films (ordinarily Part IV subject matter) are defined as 'works' for the purposes of Part IX of the Copyright Act 1968 (Cth).

14 With regard to live performances and recorded live performances so far as the performance consists of sounds, see Copyright Act 1968 (Cth) ss 189, 248A.

15 Copyright Act 1968 (Cth) s 195AN(1). 
The right of attribution of authorship/performership ${ }^{16}$ is the right to be identified, in accordance with the Copyright Act 1968 (Cth) ('the Act'), ${ }^{17}$ as the author/performer of the work/performance where any 'attributable act' is done in respect of the work or performance. 18 'Attributable' acts largely reflect the exclusive rights of the copyright owner in respect of works, films or performances. ${ }^{19}$

The right not to have authorship/performership of the work falsely attributed is the right not to have authorship of a work or an altered work or a performance falsely attributed ${ }^{20}$ by any 'act of false attribution', which acts are exhaustively defined in the Act. ${ }^{21}$

The focus of this article is on the right of integrity in a post-mortem context. Whether the right of attribution or the right not to be falsely attributed have been breached should not be difficult to establish post-mortem, since non-attribution, or false attribution, can be determined independently of the author (whether living or dead).

The right to integrity of authorship/performership is the right not to have the work or performance subjected to 'derogatory treatment', which in relation to both works and performances is defined as 'the doing, in relation to the work [or performance], of anything that results in a material distortion of, the mutilation of, or a material alteration to, the work [or performance] that is prejudicial to the author's honour or reputation'. ${ }^{22}$ In relation to works, the right extends to 'the doing of anything else in relation to the work that is prejudicial to the author's honour or reputation'.23 Infringement of the moral right of integrity occurs when a work or performance is 'subjected to derogatory treatment'. ${ }^{24}$

\section{B Posthumous provisions}

For published works, moral rights expire 70 years after the death of the author. ${ }^{25}$ For literary, dramatic or musical works unpublished at the death of the author, moral rights expire 70 years after the first act of publication, ${ }^{26}$ which could occur more than 70 years post-mortem, and may never occur.

Moral rights were introduced at least in part to comply with Australia's obligations pursuant to the Berne Convention. ${ }^{27}$ With some leeway permitted, ${ }^{28}$ Berne required those

16 Ibid ss 193(1), 195ABA(1).

17 In the manner set out in ss 195-195AB; 195ABC-195ABE

18 Ibid ss 193(2), 195ABA(2).

19 Ibid ss 194, 195ABB.

20 Ibid ss 195AC(1), 195AHA(1).

21 Ibid ss195A-H, 195AHB-C.

22 Ibid ss 195AJ(a) (works), 195AK (artistic works), 195AL (films), 195ALB (performances).

23 Ibid ss 195AJ(b), 195ALB.

24 Ibid s 195AQ(2).

25 Ibid s 33(2).

26 Ibid s 32(3).

27 Commonwealth, Parliamentary Debates, House of Representatives, 8 December 1999, 13026 (Daryl Williams). See also Cate Banks, 'Lost in Translation: a History of Moral Rights in Australian Law 1928 - 2000 (Part 1)' (2007) 11 Legal History 197, 222; Cate Banks, 'Lost in Translation: a History of Moral Rights in Australian Law 1928 - 2000 (Part 2)' (2008) 12 Legal History 99, 103.

28 Berne Convention for the Protection of Literary and Artistic Works, 828 UNTS 221 (entered into 
rights to be maintained after the author's death 'at least until the expiry of the economic rights' ${ }^{29}$ In the convoluted history leading up to the enactment of Australia's moral rights, ${ }^{30}$ posthumous rights were not deeply contentious. The only agitation of note was the lobbying by the Screen Producers Association of Australia for the right of integrity to cease on the death of the author. ${ }^{31}$ In a departure from the draft bill and the 1997 bill, this was reflected in the 1999 bill. $^{32}$ The brief explanation for the change was that the 'changes reflect consultations with the film and television industry'. ${ }^{33}$

However, this was neither consistent with Australia's obligations under the Berne Convention, nor the recommendation of the Senate Legal and Constitutional Legislation Committee, and was criticised by representatives of 'authors of literary, dramatic, musical and artistic works'. ${ }^{4}$ The then government accepted the argument that conventional authors should be treated differently from makers of films, and the 1999 bill was amended during its passage through Parliament to reflect the existing position whereby protection is provided for the copyright term, except in the case of films. ${ }^{35}$

\section{Remedies}

The possible remedies for breach of moral rights include an injunction, ${ }^{36}$ damages for loss, 37 a declaration that the moral rights of the author have been infringed, ${ }^{38}$ an order that the defendant make a public apology for the infringement, ${ }^{39}$ or an order that the derogatory treatment of the work be removed or reversed. ${ }^{40}$ In deciding an appropriate remedy, the court may consider a number of factors. ${ }^{41}$

force 9 September 1886) art 6bis(2) ('Berne Convention') provides that 'Countries whose legislation, at the moment of their ratification of or accession to this Act, does not provide for the protection after the death of the author of all the rights set out in the preceding paragraph may provide that some of these rights may, after his death, cease to be maintained'.

29 Ibid.

30 Developments of note were the Copyright Law Review Committee, Report on Moral Rights (1988); Department of Communications and the Arts, 'Proposed Moral Rights Legislation for Copyright Creators' (Discussion Paper no 52, Attorney-General's Department, 1994); exposure draft Copyright Amendment Bill 1996 (Cth); Copyright Amendment Bill 1997 (Cth); Senate Legal and Constitutional Legislation Committee, Parliament of Australia, Consideration of Legislation Referred to the Committee, Copyright Amendment Bill 1997 (October 1997), and finally the Copyright Amendment (Moral Rights) Bill 1999 (Cth).

31 See Senate Legal and Constitutional Legislation Committee, Parliament of Australia, Consideration of Legislation Referred to the Committee, Copyright Amendment Bill 1997 (October 1997) [2.98].

32 See Copyright Amendment (Moral Rights) Bill 1999 (Cth) s 195AM(1).

33 Commonwealth, Parliamentary Debates, House of Representatives, 31 October 2000, 21717 (Daryl Williams).

Ibid 21714.

Ibid 21717.

Copyright Act 1968 (Cth) s 195AZA(1)(a).

Ibid s 195AZA(1)(b).

Ibid s 195AZA(1)(c).

Ibid s 195AZA(1)(d).

Ibid s 195AZA(1)(e).

Ibid s 195AZA(2). 
The focus of this article is whether a cause of action can be established, post-mortem. The question of what, if any, damages should be awarded for infringement of the moral right of integrity post-mortem, is explored in a separate forthcoming article by the author.

\section{THE RIGHT OF INTEGRITY POST-MORTEM}

In Shakespeare's Richard II, Thomas Mowbray, Duke of Norfolk, states:

Mine honour is my life. Both grow in one.

Take honour from me, and my life is done. (I.i.177-9, 182-3)

This article subverts Mowbray's final line: take life away, and is honour 'done'?

The right of integrity mandates a discussion of three concepts - prejudice, reputation, and honour, none of which are defined in the Act or substantially explained by an Australian court. Prejudice to reputation may be established objectively, in the absence of the author. Therefore it is not discussed in this article.

\section{A 'Is prejudicial'}

The right of integrity requires that the defendant's conduct 'is prejudicial' to either honour or reputation. ${ }^{42}$ Some case law and commentators suggest that 'prejudicial' may require only a propensity ${ }^{43}$ or capacity ${ }^{44}$ to harm, rather than evidence of actual harm. ${ }^{45}$ In alleviating the burden of establishing evidence of harm in fact, this approach better protects the interests of both living and deceased authors. Even if prejudice in fact must be established, tangible evidence of economic or other quantifiable damage is unnecessary. ${ }^{46}$

42 Ibid ss 195AJ (literary, dramatic or musical works), 195AK (artistic works), 195AL (films), 195ALB (performances).

43 Elizabeth Adeney, The Moral Rights of Authors and Performers: an International and Comparative Analysis (Oxford University Press, 2006) [18.58]-[18.60]; Elizabeth Adeney, 'The Moral Right of Integrity: The Past and Future of "Honour"' (2005) 2 Intellectual Property Quarterly 111, 129; Elizabeth Adeney, 'The Moral Right Of Integrity Of Authorship: A Comparative View Of Australia's Proposals To Date' (1998) 9 Australian Intellectual Property Journal 179, 188-9.

44 Dennis Lim, 'Prejudice to Honour or Reputation in Copyright Law' (2007) 33 Monash University Law Review 290, 293.

45 See Perez v Fernandez [2012] FMCA 2 (10 February 2012) [97] ('Perez'), although Driver FM clearly considered that prejudice had been established, finding that Mr Perez's reputation did not suffer any 'lasting damage': at [107]; in Prise de Parole Inc v Guérin, Éditeur Ltée (1995) 66 CPR ( $\left.3^{\text {rd }}\right) 258$ (Federal Court of Canada), 265, the Court held that the right of integrity 'does not require the plaintiff to prove prejudice to his honour or reputation', suggesting that actual harm need not be demonstrated; Lim, ibid 293; and Adeney, 'The Moral Right of Integrity: The Past and Future of "Honour"' above n 43, 129. For the contrary view that the fact of having been prejudiced may need to be established, see Jani McCutcheon, 'Perez $v$ Fernandez - Australia's First Decision on the Moral Right of Integrity' (2013) 23(3) Australian Intellectual Property Journal 174.

46 Perez [2012] FMCA 2 (10 February 2012) [60], [95]-[96]. Support for this can also be found in Weiss v Prentice Hall Canada Inc (1995) 66 CPR (3rd) 417 (Ontario Court (General Division)) [30]. This is also consistent with defamation law: see, eg, Cerutti v Crestside Pty Ltd [2014] QCA 33 (28 February 2014) and the cases cited therein. 


\section{B Meaning of 'honour'}

Many scholars have interrogated the meaning of 'honour' ${ }^{47}$ in the absence of judicial or legislative clarification. Case law has failed to consider honour separately from reputation. ${ }^{48}$ Because 'honour' is a different word to 'reputation', and is deliberately expressed as an alternative to reputation, it must have a different meaning to 'reputation', whatever that meaning may be. ${ }^{49}$

'Honour' has various shades of meaning, 50 many blurring into reputation. Honour can be subjectively determined ('you offend my honour'). Like reputation, honour can also be measured objectively. ${ }^{51}$ We may refer to someone as 'a person of honour', suggesting they are regarded, objectively, as having high moral standards. However, an objective determination of honour risks merely repeating the reputation element in the right of integrity, probably using the same objective measure. What can explain such a deliberate statutory tautology? To avoid superfluity, the primary function of an inclusion of honour must be to protect the author's more subjective response to the defendant's conduct. The question is how that response should be articulated after the author's death, if indeed it can be. Subjectivity and death seem mutually exclusive.

The only Government source separately discussing honour and comparing it to reputation states:

the term 'honour' is generally associated with personal integrity and how a person considers he or she is perceived. 'Reputation', on the other hand, is associated more, in the defamation context, as relating to a person's professional, business or personal standing in the community. ${ }^{52}$

US science fiction writer Lois McMaster Bujold once wrote '[r]eputation is what other people know about you. Honor is what you know about yourself.' 53 Another writer has suggested that 'the post of honour is a private station'. ${ }^{54}$ Ricketson argues that 'the reference to "honour" indicates that more subjective factors are to be taken into account, involving a consideration of the way that authors think about themselves and their artistic integrity'. ${ }^{55}$ These comments suggest honour is subjectively determined, ${ }^{56}$

47 See, eg, Patricia Loughlan, 'The Right of Integrity: What is in That Word Honour? What is in That Word Reputation' (2001) 12 Australian Intellectual Property Journal 189; Lim, above n 44; Adeney, 'The Moral Right of Integrity: The Past and Future of "Honour"', above n 43; Adeney, Moral Rights, above n 43, [18.65].

48 See the examples discussed in Lim, above n 44, 297; Harrison v Harrison [2010] 25 FSR 604, and the case law discussed further below.

49 See Lim, above n 44, 293-4; Adeney, 'The Moral Right of Integrity of Authorship: A Comparative View', above n 43, 188.

50 Honour can be used as a verb (we generally try and 'honour the wishes of the dead'), or a noun ('a woman's honour is all that she has'), however these meanings are not pursued in this article, given their peripheral relevance to the moral right of integrity.

51 See, eg, the discussion in Lim, above n 44, 295-7 and Loughlan, above n 47, 191

52 Department of Communications and the Arts, above n 30, 45 [3.49].

53 Lois McMaster Bujold, A Civil Campaign (Baen, 1999) 293.

54 Joseph Addison, Cato: A Tragedy (1713) Act IV Scene 4.

55 Staniforth Ricketson and Christopher Creswell, The Law of Intellectual Property: Copyright, Designs \& Confidential Information (Thomson Reuters, 1984) vol 1 [10.110].

56 See, eg, Adeney, 'The Moral Right of Integrity: The Past and Future of "Honour"', above $n$ 43, 125-6. See Loughlan, above n 47, 191, for the contrary view that honour should be 
although dictionary definitions of honour do not always corroborate that meaning. ${ }^{57}$ While perhaps not determinative, nor mandatory, the author's actual subjective response to the defendant's conduct is at least relevant to the question of harm to honour.

\section{Can honour be prejudiced post-mortem?}

Ruminating on honour, Shakespeare's Falstaff questioned:

What is honour? A word. What is in that word

honour? What is that honour? Air. A trim

reckoning! Who hath it? He that died a

Wednesday. Doth he feel it? No. Doth he hear it?

No. 'Tis insensible then? Yea, to the dead.

Henry The Fourth Part I (V, ii, 132-135)

Falstaff not only confirms the possibility of posthumous honour, but reserves honour exclusively to the dead. More relevantly, Falstaff explains the paradox of honour: only those who die obtain it, but in death cannot feel or hear it. For present purposes, if dead authors are 'insensible' to honour, can they be prejudiced by an injury to it?

It is tempting to consider the question as inconsequential, because posthumous prejudice to reputation can always be relied upon. However, prejudice to reputation may be impossible to establish, in which case establishing posthumous harm to honour may be critical. The passage of time may have snuffed out the author's reputation. Alternatively, the author's reputation may simply be unaffected by the defendant's conduct. Indeed, prejudice to authorial reputation may occur less frequently than initially thought. Unlike the tort of defamation, the moral right of integrity relies on a defendant attacking an author's work, not an author's character. It is not immediately apparent why the mistreatment of a work by a third party would prejudicially affect the author's reputation. Society may be more likely to condemn the defendant engaging in the improper conduct, rather than the victim of that conduct. A living author's reputation may be vulnerable if community members mistakenly assume that the author is somehow responsible for the mistreatment of the work. However, such an inference is far less likely in a post-mortem context. A dead author cannot place Christmas ribbons on their sculpture, or authorise that conduct. 58

Others have explained how reputations may even be enhanced by the defendant's conduct (such as an editorial improvement to a manuscript). ${ }^{59}$ Further, an author may have no reputation in respect of the work if the author remained anonymous or the work was never published. For example, in Boudreau $v \operatorname{Lin}^{60}$ a professor revised a student's coursework paper, and published it under his own name without the student's

determined exclusively by reference to an objective standard.

See the dictionary definitions of honour discussed in Lim, above n 44, 295, and Loughlan, above n 47, 191 n 8.

See Snow v Eaton Shopping Centre Ltd (1982) 70 CPR (2nd) 105 (Ontario High Court) ('Snow') discussed further below.

This and other examples of improved reputation, which may nevertheless result in harm to honour, can be found in Loughlan, above n 47, 190-1, and Lim, above n 44, 294.

Boudreau v Lin (1997) 75 CPR (3rd) 1 (Ontario Court (General Division)), 14. 
knowledge or authority. Without discussion, ${ }^{61}$ the Court found that a breach of integrity had occurred. However no damages were awarded because there was no evidence of 'any loss to the plaintiff's reputation' ${ }^{62}$ It is difficult to see how the student's reputation could be affected when he was not named in the published paper, and his coursework paper was never published. In those circumstances, arguably the only basis for complaint would be the harm to the student's honour, to which the Court made no reference.

Thus in many instances, the objective honour or reputation of the author may be untainted, even if subjectively the author would be offended. ${ }^{63}$ However, there is a real question as to whether anyone but the author can lead evidence of harm to honour. In Prise de parole Inc v Guérin, éditeur Ltée the Court stated:

[Section] 28.2(1) does not require the plaintiff to prove prejudice to his honour or reputation; rather, it must be proved that the work was distorted, mutilated or otherwise modified 'to the prejudice of the honour or reputation of the author'. In my view, this nuance justifies the use of a subjective criterion - the author's opinion - in assessing whether an infringement is prejudicial.

It has, moreover, been recognized by the courts that this concept has a highly subjective aspect that in practice only the author can prove. ${ }^{64}$

This depends on the meaning ascribed to honour. A subjective measure of personal honour emphasises its interior nature and the incongruity of a third party advancing the author's honour. If personal honour can only be measured subjectively, how can it be defended once the author dies? How can any person other than the author possibly know when the author's personal honour has been harmed? Does personal honour, being linked so intimately to the author, thus necessarily evaporate on death, and with it possibly a cause of action for breach of the moral right of integrity? ${ }^{65}$ In Fuensanta $v$ Antena, a Spanish court held that a deceased author's moral right of integrity had not been infringed by the parody of his musical work because 'we are facing a second generation right-its defence being exercised by the heirs of the authors who defend a right which is not directly linked to their personality in that there is no work emerging from their inspiration and creation'. ${ }^{66}$

Some commentators argue that the moral right of integrity cannot, and should not, be protected post-mortem. For example, Professor Kwall argues:

An author's external work embodies her personal meaning and intended message and thus is reflective of her individual, intrinsic creative process. No one, not even the author's spouse and children, can substitute their personal judgment regarding the substance of the author's meaning and message of her work. ${ }^{67}$

61 Presumably the court considered the breach obvious. See Lim, above n 44, 304. Presumably, prejudice should be able to be inferred in obvious cases, for example, a graphic pornographic alteration of a famous children's drawing.

62 Boudreau v Lin (1997) 75 CPR (3rd) 1 (Ontario Court (General Division)), 14 (emphasis added).

63 See the examples of infringement of the French moral right of integrity in Adeney, Moral Rights, above n 43, [8.73], [8.80], [8.82].

64 Prise de parole Inc v Guérin, éditeur Ltée (1995) 66 CPR (3 $\left.3^{\text {rd }}\right) 258$ (Federal Court of Canada), 265 (emphasis added).

65 Assuming a reputational lacuna.

66 Fuensanta v Antena 3 TV SA [2001] ECDR 23 [26] (emphasis added).

67 Roberta Kwall, The Soul Of Creativity: Forging a Moral Rights Law For the United States (Stanford University Press, 2009) 160. 
Of course, an author may have articulated the meaning and message of their work while living, and even described how particular conduct would corrupt it. In such circumstances, the author's voice should be permitted to reach from the grave.

Whether common law formulations of the right of integrity protect the author's meaning and message is in any event questionable. Ostensibly, the Australian right of integrity restrains conduct in relation to a work which may prejudice the author's honour or reputation. That may involve an assessment of whether the author's meaning and message has been disturbed, but not necessarily. ${ }^{68}$ The defendant's act may not affect the message of the author's work. The offence to the author's honour may be contextual, for example exhibiting the author's artwork in association with other works that are manifestly inferior. ${ }^{69}$ In any event, this approach presumes that only the author can articulate the meaning or message of their work, and indeed that the author would have prescribed a particular meaning to the work, when this may not be the case. Many authors accept and desire that their audience will accord their own subjective meanings to their work, and postmodern theory would mandate as many meanings as there are textual interpreters.

However, Professor Kwall's argument raises an important question: is it imperative that the court hears from the author personally on the question of that author's private honour? ${ }^{70}$

This is in effect what occurs in France and Greece post-mortem. In France, the moral right of integrity protects the author's right to respect for the work. ${ }^{71}$ This entails both the right to preserve the work in its original form, and the right to protect the spirit of the work by prohibiting use in a manner and context that was not intended by the author. ${ }^{72}$ The question in France, post-mortem, is whether the heirs have been faithful to their 'duties of allegiance to the author's will', 73 which correspondingly requires evidence of the author's will. ${ }^{74}$ It makes post-mortem enforcement of moral rights particularly problematic because the author can no longer be interrogated as to his will,

68 In particular, harm to reputation may not require any evidence concerning the author's meaning or message. It may simply require some objective assessment as to whether the defendant's conduct has harmed the author's reputation.

69 Note s 195AK(b) of the Act, which provides that derogatory treatment of an artistic work includes 'an exhibition in public of the work that is prejudicial to the author's honour or reputation because of the manner or place in which the exhibition occurs'. Although, even here it could be argued that this corrupts the message of 'superiority' inherent in the author's work.

70 See Lim, above $\mathrm{n} 44,321$, noting that if an author is personally unable to give evidence, for example, because he or she is dead, and there is no alternative source of evidence of the author's subjective response, the only alternative would be an infringement action based on prejudice to the author's reputation.

71 Intellectual Property Code (France) art L 121-1.

72 Adeney, Moral Rights, above n 43, [8.63].

73 Elisabeth Logeais, 'Post-Mortem Exercise of Copyright in French Law: Old Debates, New Issues' (1991) 2(6) Entertainment Law Review 185, 186, citing Henri Desbois, Le Droit d'auteur en France (Dalloz, 3rd ed, 1978) [466], [569].

74 See Sylvie Nerisson, 'Perpetual Moral Rights: a Troubling Justification for a Fair Result' (2005) 36(8) International Review of Intellectual Property and Competition Law 953, 953-4, citing Hugo v Plon, Cour d'appel de Paris [Paris Court of Appeal], 2003/06582, 31 March 2004 reported in [2005] ECDR 27. 
and the author will rarely have unequivocally expressed his will on the particular conduct at issue while alive. Thus, post-mortem, the extent to which the author's will can be determined through some other means becomes critical. The French courts are very reluctant to divine the author's wishes:

It is not for the judge or any third party to express an opinion on the intention of the author;

the right owner of the moral right is the only person qualified to exercise it. ${ }^{75}$

The situation in Greece is similar. After the death of the author, the moral rights pass to the author's heirs, who must exercise the rights 'in compliance with the author's wishes, provided that such wishes have been explicitly expressed' ${ }^{76}$

In Australia, the different formulation of the moral right of integrity permits a different approach. The statute does not expressly or implicitly require the intention of the author to be made known. ${ }^{77}$ It would be undesirable to interpret honour such that, post-mortem, evidence of the particular subjective response of the author is obligatory. This would compromise the post-mortem reach of moral rights, except in rare cases where the author expressed views about the defendant's particular conduct while alive, such as the late member of the Beastie Boys referred to above. That would be inconsistent with Parliament's expressed intention to prohibit prejudice to honour post-mortem, and the deliberate enactment of a provision in the knowledge that the chief witness would never be able to give evidence.

Mandating authorial evidence would also ignore the moral rights theory that 'the author's personality continues beyond death', 78 which justifies the post-mortem grant of moral rights. ${ }^{79}$ It would also impede the broader social benefit of preserving the integrity of cultural heritage, an understandable policy foundation of moral rights. ${ }^{80}$ While Australia's obligations pursuant to the Berne Convention partly explain the introduction of moral rights, 81 the need to recognise 'the great importance of respect for the integrity of creative endeavour' 82 and 'the importance to Australian culture' of works and 'of those who create them' 83 was said to be a 'more important' 84 consideration. Mandatory authorial evidence would hamper both the protection of the

75 Tribunal de Grande Instance de Paris $3^{\text {rd }} \mathrm{Ch}$ [3 ${ }^{\text {rd }}$ Chamber of the Paris Grand Instance Court], Jerome London et SACD v La Compagne Brut de Béton, 15 October 1992 reported in RIDA 225 (January 1993), cited in Gillian Davies and Kevin Garnett, Moral Rights (Thomson Reuters, 2010) [12-012].

76 Copyright Act (Greece) art 12(2).

77 See also Adeney, 'The Moral Right of Integrity: The Past and Future of "Honour"', above n 43,127 , arguing that the wording of art 6bis of the Berne Convention suggests evidence of subjective response is unnecessary to a finding of infringement because the critical issue is whether the defendant's actions have the propensity to harm honour.

78 Adeney, 'The Moral Right of Integrity of Authorship: A Comparative View', above n 43, 189.

79 Logeais, above $n$ 73, 185

80 Martin A Roeder, 'The Doctrine of Moral Right: A Study in the Law of Artists, Authors and Creators' (1940) 53 Harvard Law Review 554, 575.

81 Commonwealth, Parliamentary Debates, House of Representatives, 8 December 1999, 13026 (Daryl Williams). See also Banks, 'Lost in Translation (Part One)', above n 27, 222 and Banks, 'Lost in Translation (Part Two)', above n 27, 103.

82 Commonwealth, Parliamentary Debates, House of Representatives, 8 December 1999, 13026 (Daryl Williams).

83 Ibid.

84 Ibid. 
author's personality as represented in the work, ${ }^{85}$ and the preservation of Australia's cultural heritage.

It also fails to recognise that, while the author cannot give evidence of prejudice to honour, there are other acceptable methods of establishing harm to authorial honour, discussed further below. And if mandatory authorial evidence is designed to temper potential excesses of imputed authorial honour, 86 it gives insufficient regard to the defence that the infringement of moral rights was reasonable in the circumstances. ${ }^{87}$ In addition, it is likely that Australian courts will implement some kind of objective control to test the reasonableness of the presumed authorial reactions, also discussed further below.

Therefore, harm to authorial honour can and should be compensable post-mortem. However, that begs the question: absent evidence of the author's actual reactions, how should prejudice to honour ${ }^{88}$ be established and assessed post-mortem? The various options are discussed further below.

\section{MODELS FOR ASSESSING HONOUR POST-MORTEM}

This section explores various options for establishing harm to honour post-mortem, most of which overlap, and many of which could also be applied to living authors. The following section then explores objective controls to constrain unreasonable or abusive moral rights claims.

\section{A Model 1 - assessing the author's actual views}

If authorial evidence is obligatory, this may be the only relevant model. Smolensky argues that 'if an interest is incapable of being known after death, then the law cannot protect it'. ${ }^{89}$ If this approach is followed, then it suggests the need for a reform to the definition of derogatory treatment to include, as an alternative to prejudice to honour or reputation, prejudice to the work itself.

Rarely, the author may have expressed views on the impugned conduct while living, leaving clues or messages from the grave - letters, wills, biographies, or contemporary accounts. An author may have expressed a specific view on conduct threatened before

Moral rights historically derive from the 'belief that an artist, in the process of creation, injects some of his or her spirit into the art and that, consequently, the artist's personality, as well as the integrity of the work, should be protected and preserved': Cambra E Stern, 'A Matter of Life or Death: The Visual Artists Rights Act and the Problem of Postmortem Moral Rights' (2004) 51 UCLA Law Review 849, 853, quoting Ralph E Lerner and Judith Bresler, Art Law: The Guide for Collectors, Investors, Dealers, and Artists (Practising Law Institute, 2nd ed, 1998) 943.

It is generally accepted that, in assessing injury to 'honour', a purely subjective assessment of honour is undesirable since it would give considerable power to a perhaps hypersensitive author to restrain reasonable uses. See, eg, Lim, above n 44, 309-10; Adeney, 'The Moral Right of Integrity: The Past and Future of "Honour"' above n 43, 126, 129; Adeney, Moral Rights, above n 43, [18.65]; Robert C Bird, 'Of Geese, Ribbons, And Creative Destruction: Moral Rights And Its Consequences' (2011) 90 Texas Law Review 63, 68; Jon A Baumgarten, 'On the Case Against Moral Rights' in Peter Anderson and David Saunders (eds), Moral Rights Protection in a Copyright System (Griffith University, 1992) 87, 88.

Copyright Act 1968 (Cth) s 195AS(1)

89 Or the propensity for prejudice.

89 Smolensky, above n 1, 772. 
their death, or may have foreseen and judged conduct more abstractly, such as the alteration of an artwork, the writing of a sequel, the jazz arrangement of a classical piece of music, or, as in the Beastie Boys example discussed above, the use of music in advertising. Of course, doing an act contrary to the author's expressed wish does not necessarily infringe the right of integrity. ${ }^{90}$ That act must constitute derogatory treatment. The treatment foreseen by the author may not, objectively, prejudice that author's reputation. While it could prejudice the author's honour, it is likely that the author's subjective views will require some objective corroboration, discussed below.

The author's words may also need to be interpreted to determine whether they extend to the impugned act. The reliability and persuasiveness of authorial evidence may be reduced if:

a) Those views are ambiguously expressed, or only tenuously relate to the impugned conduct. Generally expressed words may be susceptible to many possible meanings.

b) The author has expressed conflicting views on an issue. The author may have relaxed or changed their views over time, or acted inconsistently with expressed views. For example, an author's statement that he or she would not countenance a sequel to their novel would have little probative value if that author had then licensed a screenplay which was in fact a sequel to the novel.

c) The views were expressed long before the author died. For example, if an author died in his or her eighties, the passage of time and the maturation of the author may make views expressed in the author's twenties less reliable.

Even famous authors, who maintain diaries, and are broadly quoted and recorded, may leave ambiguous evidence on a particular use of their work. For example, in Hugo $v$ Les Editions Plon plc, ${ }^{91}$ Victor Hugo's great-great grandson alleged that two sequels to Les Miserables infringed Victor Hugo's moral right of integrity, which in France is a perpetual right. As mentioned above, the French right of integrity demands respect for the work. The lack of respect was alleged to be 'a misunderstanding of the social context and the values expressed by Les Miserables, but also and above all of a transformation of the principal characters, a transformation bordering on their reversal and totally changing the perspective of the work'.$^{92}$ The chief transformation was the resurrection of Javert, a central character of Les Miserables who had clearly committed suicide towards the end of Les Miserables, and his transformation from the obsessive, cool and unrelenting pursuer of Jean Valjean in Les Miserables into a benevolent character. The

90 In comparison to the situation in France, discussed further below.

91 In all, there were three substantive decisions in the Hugo $v$ Plon litigation: commencing with Hugo $v$ Plon, Cour d'appel de Paris [Paris Court of Appeal], 2003/06582, 31 March 2004 reported in [2005] ECDR 27; then Plon SA v Hugo, Cour de cassation [French Court of Cassation], 30 January 2007 reported in [2007] ECDR 9; and ending with La Société des gens de lettres de France v SA Les Éditions Plon, Cour d'appel de Paris [Paris Court of Appeal], 07/05821, 19 December 2008 reported in (2009) 40 International Review of Intellectual Property and Competition Law 979.

92 La Société des gens de lettres de France v SA Les Éditions Plon, Cour d'appel de Paris [Paris Court of Appeal], 07/05821, 19 December 2008 reported in (2009) 40 International Review of Intellectual Property and Competition Law, 979, 982. 
other transformation of character was the portrayal of Cosette and Marius, who were deeply in love and about to lead an idyllic life at the conclusion of Les Miserables, as inexplicably disaffected participants in a failing marriage a mere three months later.

The defendant publisher relied on an 1878 speech by Hugo to the International Literary Congress, in which he stated:

Before publication, the author unarguably has unlimited rights ... But as soon as the work is published the author no longer has absolute control over it. At that point another character takes control, which you may call as you will: human spirit, public domain, society. It is this character which says: I am here, I take this work, I do with it that which I believe I must do, I the human spirit ... Once the author is dead ... I declare that if I had to choose between the rights of the author and the rights of the public domain, I would choose the rights of the public domain ... We must work for all before working for ourselves ... The writer, as a writer, has only one heir, that is the heir through spirit, the human spirit, the public domain. Here lies absolute truth. ${ }^{93}$

The publisher Plon also relied on an 1870 diary entry, where Hugo wrote:

people have stopped asking me for permission to speak my works in theatres. Everywhere, people speak my works without asking for my permission. These people are right. That which I write is not mine. I am a public entity. 94

Finally, Plon relied on the failure by both Hugo and his heirs to condemn or oppose dramatic adaptations of his books or characters.

In contrast, Pierre Hugo relied on Hugo's statement that 'once the book is published, once the sex of the book, whether masculine or not, has been identified and proclaimed, once the child has cried his first cry', the book should be left to 'live or die as it is'. ${ }^{95}$

He also relied on a note to the definitive edition of 'The Hunchback of Notre Dame', in which Hugo stated that:

the author cannot comprehend how fresh developments could be added to a work of this character after its completion. According to his idea, a romance is born in a manner that is, in some sort, necessary, with all its chapters; a drama is born with all its scenes ... Grafting and soldering take badly on works of this nature, which should gush forth in a single stream and so remain ... This now, is his entire work, such as he dreamed it, such as he made it, good or bad, durable or fragile, but such as he wishes it. ${ }^{96}$

Finally, he relied on Victor Hugo's note to his publisher, sent with the last chapter of Les Miserables, where Hugo stated that '[i]f this ending is not deemed moving, I will renounce writing for ever'. ${ }^{97}$

The Cour d'appel in 2004 held that in none of these documents did Hugo express a "wish to allow the moral rights attached the whole of his literary work to "lapse" into

93 Hugo v Plon, Cour d'appel de Paris [Paris Court of Appeal], 2003/06582, 31 March 2004 reported in [2005] EDCR 27 [30].

94 Ibid [31].

95 Ibid [32].

96 La Société des gens de lettres de France v SA Les Éditions Plon, Cour d'appel de Paris [Paris Court of Appeal], 07/05821, 19 December 2008 reported in (2009) 40 International Review of Intellectual Property and Competition Law 979, 980-1.

97 Hugo v Plon, Cour d'appel de Paris [Paris Court of Appeal], 2003/06582, 31 March 2004 reported in [2005] EDCR 27 [35]. While it was not entirely clear what aspect of the 'ending' Victor Hugo was referring to, the applicants argued that this expressed Hugo's desire to retain the ending as it stood (and with the characters who had died remaining dead). 
the public domain', 98 and that the evidence established that he 'would not have accepted' a third party writing a sequel. ${ }^{99}$

The Court relied in particular on Hugo's letter to his publisher, holding that Hugo 'forcefully marked his will that this ending should not be the subject of any alteration, for what worse punishment could a writer inflict upon himself than that of no longer writing?' 100

The decision was criticised, in part because 'the decision could just as easily have reached the contrary conclusion, again by using Hugo's writings,' ${ }^{101}$ and arguably the more generally expressed views at the International Literary Congress should have been preferred. ${ }^{102}$

Plon appealed to the Cour de cassation, which criticised the Cour d'appel's 'disregard of creative freedom' and its failure to explain how the sequels 'would have changed Victor Hugo's work'103 or how 'confusion would arise as to their authorship'. ${ }^{104}$ The Cour de cassation remitted the matter back to the Cour d'appel to be considered in accordance with the principles it established.

In 2008, a newly constituted Cour d'appel considered the same evidence, but concluded that Hugo's views on a sequel could not 'be determined with certainty', since he made no 'precise statement' on the issue. ${ }^{105}$ Hugo's diary entry (' $[w]$ hat I write does not belong to me'), reflected a wish for 'public access to his works ... to be as simple as possible and not inhibited by anyone holding a right to the work'. ${ }^{106}$ While Hugo's note to The Hunchback of Notre Dame (condemning '[g]rafting and soldering') evinced 'a respectful position with respect to the works of a writer', this didn't mean that Hugo 'was hostile to any adaptation or imaginary continuation made of his works'. 107 The Court also pointed out that Hugo himself adapted The Hunchback of Notre Dame as an opera libretto and accepted stage adaptations of the novel, ${ }^{108}$ however here the Court failed to appreciate the difference between an adaptation true to the spirit of the original tale and a new imagined sequel.

The requirement of certainty or a precise statement by the deceased author clearly increases the evidentiary burden on the author's heirs, in most cases insurmountably.

In comparison to the Les Miserables case, another French court had no hesitation in enjoining the publication of a colourisation of a black and white film by John Huston, after his death. The Court held that black and white was Huston's 'deliberate aesthetic

98

99 Ibid [36].

Ibid [37].

100 Ibid [35].

101 C Caron, 'Communication Commerce Électronique' 27 (May 2004), cited in Nerisson, above n 74, 957.

102 Nerisson, above $\mathrm{n} 74,957$

103 Plon SA v Hugo, Cour de cassation [French Court of Cassation], 20 January 2007 reported in [2007] ECDR 9 [9].

104 Ibid.

105 La Société des gens de lettres de Francev SA Les Éditions Plon, Cour d'appel de Paris [Paris Court of Appeal], 07/05821, 19 December 2008 reported in (2009) 40 International Review of Intellectual Property and Competition Law 979, 980.

106

106 Ibid.

108 Ibid 980-1.

108 Ibid. 
choice' and colorisation violated 'the creative activity' of the author, ${ }^{109}$ appearing to accept the plaintiffs' arguments that colourisation altered 'the very essence of the work' ${ }^{110}$ Importantly, the Court could point to evidence clearly demonstrating that Huston was formally opposed to colourisation during his life, in particular his statement in relation to his film The Maltese Falcon: 'I wanted to shoot it in black and white like a sculptor chooses to work in clay, to pour his work in bronze, to sculpt in marble'. ${ }^{111}$ Similarly, Samuel Beckett's clearly expressed intention not to have women perform Waiting for Godot was enough to enjoin a director from casting women. ${ }^{112}$ And in Greece, the heirs of a composer successfully challenged a public performance of the composer's works with other compositions of a style which had been criticised by the author. 113

Thus at least in France and Greece the absence of unequivocal expression by the author as to whether the conduct in question would be tolerated seems critical. Counsel for Plon in the Les Miserables case has said 'I think if Victor Hugo had indicated that he didn't want a sequel, the Court would have been obliged to follow [that direction]' ${ }^{114}$

Should a similar approach be adopted in Australia, the lesson is clear: authors would be well advised to, as far as possible, clearly articulate their wishes with respect to their works before their death, and properly brief their personal representatives.

\section{B Model 2 - a hypothetical enquiry into honour}

Another approach to establishing harm to honour post-mortem is to try and establish how the author would have felt regarding the impugned conduct. This will be a hypothetical enquiry into honour, with the author's response imputed. In those circumstances, 'dead artists' intentions can only be gleaned second-hand'. ${ }^{115}$ While second-hand evidence may not be the best evidence, it could nevertheless be sufficiently persuasive to establish a cause of action. This would require evidence from persons who knew the author, and/or who knew the author's work. Evidence may be led by friends and family, biographers, experts or archivists. This evidence could lead to a reasonably clear picture of how the author would have reacted to the impugned conduct. However, there are a number of difficulties with this model. First, it relies on the existence of some evidence from which the imputed response can be deduced. There may be little or no documentary evidence available and the passage of time may mean there are few, if any, living witnesses who can give evidence relating to the character of the author. Assuming the availability of documentary and/or oral evidence, the model presumes a relatively homogenous understanding of the author emerging from those sources, and, correspondingly the speculative authorial response. However, it is equally likely that evidence may be conflicting, since each of these potential witnesses may 'know' the author in different ways, and documentary evidence may paint a contradictory picture.

109 Turner Entertainment Co v Huston, Cour d'appel de Versailles [Versailles Court of Appeal], 19 December 1994 reported in (1995) 16(10) Entertainment Law Reporter 3, Pt III [10].

110 Ibid Pt II [2].

111 Ibid Pt III [9].

112 TGI Paris, 3e ch., 15 Oct. 1992: RIDA 1/1993, 225.

113 Davies and Garnett, above n 75, 14-034.

114 Interview with Paul Lombard (6 March 2012).

115 Henry Lydiate, 'Posthumous Legal and Ethical Issues' (2007) 8 Tate Papers <http://www.tate.org.uk/research/publications/tate-papers/posthumous-legal-andethical-issues>. 
Thus the problems of ambiguity inherent in model 1 may also infect model 2 . In particular, it does not necessarily follow that the witnesses have a good understanding of the author as an author, although that is perhaps something that the court can take into consideration. There is also a danger that the witnesses may, even unconsciously, be ascribing responses to the author which are in fact the witness's own personal responses.

Finally, there is a risk that witnesses will propose imputed authorial reactions which are extreme, hypersensitive or irrational. In addition or alternatively, the LPR may abuse the author's moral rights, and may prefer their own interests to the author's. Therefore it is essential that this model is controlled by an objective safeguard establishing the reasonableness of the imputed reactions, discussed further below.

\section{Model 3 - establishing prejudice to honour through the work}

In this model, the hypothetical reactions of the author need not be invented or secondguessed. They can be ignored. Under this approach, the work - and the authorship reflected in the work - becomes the essential evidentiary source. Because the work speaks for itself, the author need not speak. Given that moral rights only arise through and in respect of works, this is an appropriate model.

This model reflects the European 'personality theory' underpinning moral rights, which proposes that, when creating a work, the author 'projects into the world part of his personality and subjects it to the ravages of public use'. ${ }^{116}$ This assumes an intimate, unbreakable connection between the author's personality and the work that reflects it. Indeed, this theory of 'imbued personality' 117 perhaps best explains post-mortem moral rights, because the author's personality necessarily persists in the work even after death. Thus while the author may have left this earth, the work remains and the author's honour can continue to be protected through it.

This is a useful post-mortem test, because the deceased author fades more into the background and the work itself can elevate to the central point of consideration. One important advantage of this model is that the primary source of evidence - the work will always be available. ${ }^{118}$ This model is superior to the 'imputed reactions' model 2, because, as mentioned, proving an author's imagined subjective responses depends on evidence from a number of sources, which may not be available. This model also avoids the artificiality of the LPR needing to second-guess what the author would have thought, and it better reflects the public interest in maintaining the integrity of works rather than the integrity of the author.

How then does this model establish prejudice to the author's honour as demanded by the statute? One could argue that the work, by reason of its very nature, reflects what the author did, thought, and wanted.119 This relies on 'discovering' authorial

116 Roeder, above n 80, 557.

117 Brian A Lee, 'Making Sense of "Moral Rights": Artists' European Style Intellectual Property Protections Within the American System' (22 April 2007) Yale Law School Legal Scholarship Repository Student Prize Papers, 30 <http://digitalcommons.law.yale.edu/ylsspps_papers/15>

118 Or at least a copy of it will be.

119 An approach with some support in the US. See, eg, Massachusetts Museum of Contemporary Art Foundation, Inc v Buchel 593 F 3d 38, 54 [41] (1st Cir, 2010), where the US Court of Appeals for the First Circuit noted that the House Report pertaining to the Visual Artists Rights Act 
perceptions in the work itself. Works cannot, of course literally 'speak'. They must be interpreted and evaluated, and herein lies the major difficulty with this model: conflicting opinions about the meaning and message of the work. However, such a 'battle of the experts' may, as is often the case, be unavoidable. Courts are competent to determine which evidence should be preferred.

Since the author's voice is necessarily silent, this approach is absolutely dependent on utilising some objective measure for determining the prejudice, discussed further below. This approach may also merge with the imputed responses approach (model 2), because the same witnesses may give evidence.

There will be circumstances where this model is inappropriate. For example, it is appropriate when works have been altered, especially where those alterations are egregious or patently offensive. However, where the prejudice is not so objectively clear and it depends more on the peculiar personal honour of the author, the imputed responses model is optimal, because it may be critical to adduce evidence from those intimately aware of the author's wishes and views on a particular issue. For example, an artist's family may be well aware that he would never have wanted to be exhibited in the same collection as an artist that he considered inferior, even if objectively that conduct does not appear prejudicial.

\section{Model 4 - inferring harm to honour}

In this model, prejudice to honour may be presumed. This would be limited to instances where the defendant's conduct was particularly egregious and patently derogatory, or where other circumstances permit the inference of derogatory treatment. In the case of deceased authors, presumption of prejudice may be appropriate where actual quantifiable damage (such as lost sales, devaluation of the author's corpus, or reduced exhibition or performance of the author's work) can be demonstrated. In those circumstances, it may be easier to draw a connection between the defendant's conduct and that loss, and to further assume that the loss was caused by the harm to honour or reputation. There is some support for this approach in Perez where, because of the particular circumstances, the Court was prepared to presume prejudice to reputation (discussed further below).

While ambiguous or conflicting statements will always obscure authorial intentions, reasonable inferences can be based on evidence other than an unequivocal instruction in relation to a certain act. For example, Vladimir Nabokov died before finishing his novel The Original of Laura, which he was writing at the time of his death in 1977. Nabakov left strict instructions in his will to destroy the work. However, far from destroying the manuscript, Nabokov's son and executor published The Original of Laura in 2009. Mixed critical responses included strongly negative condemnations of a rough work. However,

\footnotetext{
'recommended that the prejudice inquiry "focus on the artistic or professional honor or reputation of the individual as embodied in the work that is protected": quoting HR Rep No 101514 (1990), reprinted in 1990 U.S.C.C.A.N. 6925-6 (emphasis added). The appellate court also approved of the district court's conclusion in Carter $v$ Helmsley-Spear, Inc that the court should 'consider whether [the proposed] alteration would cause injury or damage to the plaintiff's good name, public esteem, or reputation in the artistic community': Massachusetts Museum of Contemporary Art Foundation, Inc v Buchel 593 F 3d 38, 54 [42] (1st Cir, 2010), quoting Carter v Helmsley-Spear, Inc 861 F Supp 303, 323 (SD NY 1994).
} 
even had it not been condemned, Nabokov's testamentary instructions to destroy the manuscript could permit an inference that he would clearly regard its publication as derogatory to his honour and reputation.

The advantage of this model is that the court itself should ordinarily be able to make the determination, which clearly eases the evidentiary burden on the author's LPR. In this sense, the court itself employs the objective control. The obvious risk with this approach is that the court may not agree with the LPR's assessment that the defendant's conduct was demonstrably (and thus presumptively) prejudicial.

\section{E Conclusions - models for evidencing prejudice to honour}

Protecting the intrinsically private aspects of authorial honour post-mortem is awkward, but necessary to give full effect to the duration of protection intended by Parliament. Each of the proposed models has merits and disadvantages, depending on the particular post-mortem circumstances. Model 1 relies on a clear articulation by the author, while living. However, such an articulation, and an unambiguous one at that, is likely to be extremely rare. Similar considerations apply to model 4, which is only appropriate where derogatory treatment can plainly be presumed. Consequently, both models 1 and 4 would only infrequently be applicable. Model 2 is perhaps the most fragile, since it relies on evidence from persons who knew the author, and/or the author's work, to engage in reasoned speculation as to how the author would have responded to the impugned conduct. The model may be unworkable due to a lack of evidence or available witnesses, conflicting or ambiguous evidence concerning the author, and the dangers of witnesses unintentionally substituting their personal reactions for the authors, or even abusing the author's moral rights. Model 3 is the preferred approach. The chief witness is the author's work, which is perpetually available. One need not worry about locating witnesses who knew the author. The model is more faithful to the normative justifications for the moral right as a personality right. The chief danger is the risk of conflicting evidence in the interpretation of the work, however, on balance the advantages of this model outweigh those concerns.

\section{OBJECTIVE CONTROLS ON PREJUDICE TO AUTHORIAL HONOUR}

Strong support for an objective control on the assessment of prejudice to honour can be found in both academic commentary, ${ }^{120}$ and, more opaquely, in Anglo-Australian case law. The case law is uncertain primarily because it fails to treat honour distinct from the more objective criterion of reputation. Perhaps the most obvious conflation of honour and reputation can be found in Harrison v Harrison, ${ }^{121}$ where the Court stated:

[the author] has put forward his honour and reputation for scrutiny in this part of his claim.

This is not easy to assess. Furthermore, there is no evidence about this matter ... There is no evidence even of the kind that one might find for example, in a County Court passing off case. Doing the best I can, the words which spring to mind to categorise [the author's] professional honour or reputation are 'very modest'. 122 Past and Future of "Honour"', above n 43; Adeney, Moral Rights, above n 43, [18.65]. 
The Court clearly regards 'honour or reputation' as a composite whole, ${ }^{123}$ and effectively subsumes honour into reputation. For instance, 'honour or reputation' are qualified with the adjective 'professional', implying that both are to be assessed by that measure (when both honour and reputation may be assessed against a more personal measure of character). This is supported by the categorisation of the author's professional honour or reputation as 'very modest', which implies that honour or reputation are quantifiable in a passing off sense, when an injury to personal honour is not always measureable in the same sense.

The merger of honour and reputation is inevitably frustrating because much of what is said by the courts can be, and probably should be, regarded as a comment on prejudice to reputation. Further, none of the Anglo-Australian decisions apply in a post-mortem context. Nevertheless, given the dearth of judicial commentary on this issue, the available case law deserves to be scrutinised for any possible guidance.

Perhaps the strongest support for an objective control on prejudice to honour can be found in Snow, 124 where the Court ordered the removal of ribbons from the plaintiff's sculpture of 60 geese suspended from a shopping centre ceiling. The ribbons were added as part of a Christmas display. O'Brien J stated that the words " prejudicial to his honour or reputation" ... involve a certain subjective element or judgment on the part of the author so long as it is reasonably arrived at'. ${ }^{125}$ Given that an author's subjective response is strictly irrelevant to prejudice to reputation, this seems like a statement concerning honour. This is supported by His Honour's note of the plaintiff's 'belief that his naturalistic composition has been made to look ridiculous'. ${ }^{126}$

In Prise de Parole Inc v Guérin, Éditeur Ltée ${ }^{127}$ the Court imposed a stringently objective standard. Here, the defendants cut the plaintiff's novel by a third of its original size, omitted plot elements, and changed the order of events. The author sued for infringement of his moral right of integrity. While noting the author's subjective evidence of shock and distress, 128 the Court focused on the detailed evidence of the author's reputation. However, the Court said 'the evidence has not shown that, objectively, as required by ... the Act, his work was modified to the prejudice of his honour or reputation'. ${ }^{129}$

In Ritchie $v$ Sawmill Creek Golf $\mathcal{E}$ Country Club Ltd, 130 the plaintiff objected to 'horrifying'131 poor quality, poster-sized enlargements of his photographs. However, the Court held that there was no infringement of moral rights. It implied that the plaintiff's response was unreasonable, since the posters were 'not so markedly different in quality from the prints as to damage the author's honour or reputation'. The Court was also influenced by the fact that 'no objective evidence of prejudice was adduced to

123 Despite referring to both honour or reputation, the court states that 'this' (singular rather than 'these' plural) is 'not easy to assess' and regards the evidence on 'this' (singular) matter being insufficient.: ibid [64].

124 (1982) 70 CPR (2nd) 105 (Ontario Court (General Division)).

125 Ibid 106 [5].

126 Ibid 106 [6].

127 (1995) 66 CPR ( $\left.3^{\text {rd }}\right) 257$ (Federal Court of Canada).

128 Ibid 266

129 Ibid (emphasis added).

130 (2003) 27 CPR $\left(4^{\text {th }}\right) 220$ (Ontario Supreme Court).

131 Ibid [51] 
support [the author's] own personal reaction'. ${ }^{132}$ In Tidy $v$ Trustees of the Natural History Museum, ${ }^{133}$ the Court considered that the author's subjective view must be 'reasonably held, which inevitably involves the application of an objective test of reasonableness'. ${ }^{134}$ Likewise, in Pasterfield $v$ Denham, 135 the Court held that '[i]t is not sufficient that the author is himself aggrieved by what has occurred' when deciding whether treatment is derogatory or not. 136

The very fact that moral rights are posthumous supports an objective control, since the actual subjective evidence from the author will rarely be available after death. This is also supported by the history of the enactment of art 6bis of the Berne Convention, which demonstrated the reluctance of the common law countries to use a test of the personal interest of the author, and insisted on honour or reputation as familiar benchmarks of defamation law (which employs an objective test). ${ }^{137}$ It is also reflected in the fact that Parliament deliberately chose not to enact the right of integrity in words similar to, or as broad as, those in civil law countries (in particular France). Finally, determining infringement based only on the subjective response of an author (real or imputed) would give that author (or the author's LPR) inordinate power to abuse the moral rights, and to establish infringement based on personal whim alone.

The reasons for employing an objective measure of control with respect to living authors also apply to deceased authors. Each of the proposed models for establishing post-mortem prejudice to honour discussed above merit some form of safeguard to avoid the risk that the LPR, or others, will overstate the injury to the author's honour, resulting in over-protection and the unreasonable restraint on legitimate uses of the work.

Therefore to ensure its relevance post-mortem, authorial honour 'must...necessarily, be established using more exclusively objective criteria, while still being kept distinct from reputation'. ${ }^{138}$ However, there is debate as to how an objective test should be formulated and applied in respect of living authors, a debate which is further complicated in a post-mortem context. Various commentators have proposed and analysed tests for objectively establishing harm to honour, ${ }^{139}$ and the (albeit cursory and inconsistent) judicial attention directed to the question will be discussed below.

In a post-mortem context, there appear to be five choices for an objective control on the proposed models for establishing prejudice to honour canvassed above:

1. In the rare case where there is evidence of an actual authorial response to the impugned conduct, the reasonableness of that response can be assessed.

2. Where there is no evidence of an actual authorial response, the reasonableness of an imputed response can be tested.

Ibid [52].

(1995) 39 IPR 501 ('Tidy’).

Ibid 504.

[1999] FSR 168.

Ibid 182.

Adeney, 'The Moral Right of Integrity of Authorship: A Comparative View', above n 43, 188. Adeney, "The Moral Right of Integrity: the Past and Future of "Honour"' above n 43, 129.

See, eg, Loughlan, above n 47; Lim, above n 44; Adeney, 'The Moral Right of Integrity: The Past and Future of "Honour"', above n 43, 129; Adeney, Moral Rights, above n 43, [18.65]. 
3. The court can disregard an actual or imputed response, and ask whether the defendant has respected the work, measured against appropriate objective standards which assess the work and the act of authorship in relation to it.

4. Where harm to honour can be presumed due to the circumstances of the case (for example, where the defendant's conduct was particularly egregious), then there is an inherent objective control already. In effect, the court accepts that no reasonable person could regard the defendant's conduct as anything but harmful to honour.

5. The court can refrain from imposing any objective control when determining if moral rights have been infringed, and/or significantly lower the applicant's evidentiary burden, and simply rely on the reasonableness defence.

It has been suggested that an objective test for the assessment of honour would 'make the "prejudice to honour" limb of the right of integrity very similar to the "prejudice to reputation" limb'. ${ }^{140}$ However, the overlap, post-mortem, between the honour and reputation limbs depends on how the test for authorial harm to both honour and reputation will be formulated, and what evidence is required to satisfy that test, neither of which has been clarified yet.

Whatever control is employed, it will be imperative to instruct the witnesses as to the relevant concept of honour. The jurisprudential failure to separate the honour and reputation elements means that no one - authors, LPRs, lawyers, witnesses or even judges - has a clear understanding of what is meant by 'honour'. In order to establish prejudice to honour, it is essential to understand what it is, particularly where there may be a reputational lacuna and prejudice to honour is the only basis for action.

Courts must also ultimately provide guidance on the particular reasonableness control that is appropriate. Is it different with respect to honour and reputation, and if so, in what way? In each case, who determines reasonableness? Is it the hypothetical reasonable man, a reasonable cross-section of the community, a reasonable author in the relevant field, ${ }^{141}$ an expert in the author's field, the author's peers, or the court? Do we ask how members of the community actually regard the author following the conduct, or do we just ask them if the author's imputed response is reasonable? If so, which members of which community: members of the author's community, experts in the author's field, the author's friends or family, or a disinterested 'typical' person? To what extent can the court itself determine questions relating to reasonableness? And how does a reasonableness control interact with the defence of reasonableness?

\section{A Model 1 - actual responses of the author}

This model would interrogate whether the author's actual response, based on the available evidence (as interpreted), is reasonable. Could the court itself make this determination, and interpret the available authorial evidence, or would it require evidence from suitable impartial witnesses? Who should these witnesses be? This may depend on the nature of the authorial evidence, the work and the impugned act. For example, a clear forewarning by an artist or author that destruction of a painting, or a

140 Lim, above n 44, 305.

141 Ibid. 
pornographic sequel to a children's novel, was untenable would hardly require additional evidence of reasonableness. However, the passage of time after death may make the author's views anachronistic, declaring impermissible that which, over time, has become largely accepted. Does it follow that those views are unreasonable? It may not be possible to avoid using contemporary standards when assessing reasonableness, given the difficulty of reaching back and judging the author's views against the standards of the time.

The cases discussed above clearly require objective evidence of prejudice, but who must give that evidence is unclear. The cases suggest that the independent corroboration could be done by 'anyone', 142 the court, 143 or experts in the author's field. ${ }^{144}$

In Snow, the author's belief that he was made to look ridiculous was shared by 'other well respected artists and people knowledgeable in his field' ${ }^{145}$ This fact seemed to be critical, and led to the Court being 'satisfied ... [that] the plaintiff's concern [that the treatment] will be prejudicial to his honour or reputation is reasonable under the circumstances'.146 The Court was apparently unwilling to objectively verify the plaintiff's subjective concern itself, insisting instead on corroboration by third-party witnesses. And not just any witnesses, but 'well respected artists and people knowledgeable in [the author's] field' ${ }^{147}$ In other words, the Court was not prepared to adopt the standard of a hypothetical reasonable person, and by implication evidence by 'typical' members of the community may not have been sufficient.

In Prise de Parole, the author needed to show 'an objective evaluation of the prejudice based on public or expert opinion' ${ }^{148}$ The author's evidence did not extend to this. Employing criteria redolent of a defamation action, the Court noted that the author had not been 'ridiculed or mocked by his colleagues or the newspapers and that he had not personally heard any complaints' ${ }^{149}$ following the defendant's conduct. The requirement of objective third party evaluation of the prejudice is consistent with Snow, however there is a suggestion that 'public' evidence would be acceptable, with 'expert' evidence being an alternative. Also consistent with Snow, the Court is apparently not prepared to, in effect, make that assessment itself using a hypothetical standard of a reasonable person. One perhaps important point of difference with Snow is the suggestion in Prise de Parole that the plaintiff would need to give evidence of actual instances of ridicule, mockery or complaints when, consistent with Snow, it should have been sufficient that the plaintiff provide evidence from professional peers that the defendant's conduct was prejudicial.

In Ritchie $v$ Sawmill Creek Golf $\mathcal{E}$ Country Club Ltd, ${ }^{150}$ the Court seems to suggest that expert evidence would be required, criticising the author for not asking his witness, who was an experienced professional photographer, whether the 'enlargements were of such

142 Tidy (1995) 39 IPR 501

143 Ritchie v Sawmill Creek Golf \& Country Club Ltd (2003) 27 CPR (4th) 220 (Ontario Supreme Court).

144 Snow (1982) 70 CPR (2d) 105, 106

145 Ibid.

146 Ibid.

147 Ibid.

148 Prise de parole Inc v Guérin, éditeur Ltée (1995) 66 CPR (3rd) 258, 265 (emphasis added).

149 Ibid

150 (2003) 27 CPR (4th) 220 (Ontario Supreme Court). 
poor quality as to offend the integrity of the author'. ${ }^{151}$ In this case, the Court essentially makes the assessment of reasonableness itself. It considered the changes to the plaintiff's work, and reached a conclusion that there was no prejudice to honour or reputation. Would the outcome have been different had the plaintiff adduced evidence corroborating his subjective response, or would the Court still have concluded that the plaintiff's subjective response was unreasonable?

In Tidy, Ratee J questioned how he could reach a conclusion regarding prejudice to the author 'without having the benefit of evidence relating to the effect of the reproduction on his reputation in the minds of other people'. ${ }^{152}$ Ratee J suggested that a reasonableness test would be applied by considering the response of 'anybody looking at the reproduced cartoons in the book'. ${ }^{153}$ That 'other people' or 'anybody' could give evidence suggests that expert evidence may not necessarily be required, but it does suggest that reasonableness is determined by reference to the views of other people, and that the Court itself could not determine the issue based on some hypothetical reasonable person.

In Harrison 154 the author of a text complained about modifications made in the second edition by another person. Clearly unpersuaded by the author's claimed examples of prejudice, Fysh J said that while '[the author] has put forward his honour and reputation for scrutiny': 155

This is not easy to assess. Furthermore, there is no evidence about this matter ... There is no evidence even of the kind that one might find for example, in a County Court passing off case. 156

His Honour warned that a claimant cannot 'amass a mound of extracted trivia and submit absent relevant evidence, that the vice lies in its cumulative effect upon a reader'. ${ }^{157}$ This suggests that the 'relevant evidence' the Court required was the effect of the defendant's conduct 'upon a reader', although the Court did not clarify whether that should be an expert reader, or an ordinary, reasonable reader. Further, the Court suggests that the author's views on his or her honour or reputation are more or less irrelevant. In a post-mortem context, while the irrelevance of the author's subjective views eases the LPR's evidentiary burden, Harrison appears to require substantial evidence objectively demonstrating measurable harm.

\section{B Model 2 - hypothetical inquiry into honour}

The question in relation to this model is whether the author's hypothetical response as advocated by the LPR and other witnesses is reasonable. In the late 1990s, Vladimir Nabakov's heir sought to restrain publication in the United States of Pia Pera's Lo's Diary, a re-telling of Nabakov's infamous Lolita from the perspective of Lolita. The

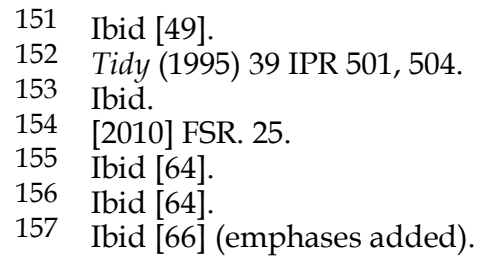


dispute was ultimately settled, but in the process Pia Pera raised some probing questions which resonate with this article:

What rights does an heir have? Does an heir have the right to stop his father's book entering into (immortal) dialogue with other works of literature, or do his rights concern merely the economic enjoyment of copyright? Is a dead author supposed to have his son's permission to go out and play with other writers? Should a dead author have to ask permission from his son before playing a match with someone else in which he could, after all, loose [sic] but also win? Is a descendent supposed to be the most reliable expert on his ancestor's work? 158

How can the reasonableness of the imputed reactions be tested? The cases discussed above suggest that a court may not be confident in making that determination, absent independent evidence. This suggests that the LPR must adduce two streams of evidence; one from those who knew the author well enough to formulate the imputed reactions, and an alternative stream of more impartial witnesses who can confirm the reasonableness of those imputed reactions.

The necessity to adduce two streams of evidence clearly complicates the evidentiary process, and consequently the time and cost of litigation. It also increases the likelihood that the witnesses in this model will overlap with witnesses in the third model establishing prejudice through the work itself, and the first model. And, as mentioned above, there is a greater risk that witnesses will become unavailable over time.

\section{Model 3 - establishing prejudice through the work itself}

In effect, this objective control determines whether the treatment of the work was reasonable, measured against appropriate objective standards. The issue is articulating those standards.

Adeney argues that for honour to be protected post-mortem, it must be based on more than authorial perception, actual or imputed. She argues that moral rights reflect community concepts of how authors should be treated, and that the right of integrity 'expresses and upholds agreed concepts of authorial dignity and of the respect due to authors through their works'. ${ }^{159}$ Therefore any interpretation of honour should reflect these community standards, rather than the actual or imputed reactions of the author. She argues that these community standards can be imported through a reasonableness control. 160

According to Adeney, honour 'needs ... to be interpreted as denoting the respect in which the work and the act of authorship should be held' ${ }^{161}$ This mandates a discussion of concepts of respect. The reference to 'respect' echoes the French right of integrity,

158 Pia Pera, 'A Moral Critique of Lolita in the Form of a Nabokovian Prank', unpublished afterword for the US publication of Lo's Diary. Pera decided not to publish the afterword after it was, in Pera's view, disclosed to Dimitri Nabakov contrary to their agreed settlement: interview with Pia Pera (13 April 2012).

159 Adeney, Moral Rights, above n 43, [18.65].

160 Ibid. See also Adeney, 'The Moral Right of Integrity: the Past and Future of "Honour"', above n $43,127$.

161 Adeney, 'The Moral Right of Integrity: the Past and Future of "Honour"', above n 43, 129. 
which, as mentioned, confers a right to respect for the 'spirit' of the work. ${ }^{162}$ In France, this means treating the work in accordance with the author's vision; however in a postmortem context evidence of the author's vision may rarely be available. Adeney suggests the test is whether the work has been treated in accordance with society's vision. She proposes that:

The right would be infringed when the respect appropriate to the work and to the authorship was absent. Courts would need to develop some yardstick to gauge what treatment is appropriate to the type of work in question - some socially imposed limitation on the work's use. 163

It would of course be very difficult to develop such legal yardsticks according to types of work, or indeed any other criterion. Each case would be very fact-dependent. Not only must the nature of the work and its authorship be taken into account, but also the nature of the defendant's act. The various permutations of the type of work and type of act are myriad. For example, writing a sequel to a novel is substantially different to attempting a 'restoration' of a 200-year-old oil painting. Each case would need to be determined according to its particular facts.

Therefore the yardstick could only be whether, according to the particular facts of the case, the respect shown to the work and its authorship was appropriate. In each case the evidence before the court would be critical. A suitable person must give evidence as to whether the defendant's conduct is appropriate, or whether it falls short of what is socially acceptable. Adeney's reference to a 'socially imposed limitation' suggests that the witnesses must be able to represent social interests in the work and the integrity of its authorship. However, society has many layers, interests, levels of expertise and members. This raises the same questions ventilated above: whose evidence should provide the objective control? Would the evidence of a representative layperson be sufficient, or would expert evidence be required, or both? It is quite conceivable that a 'typical member of the community' with no particular expertise in the author's creative domain may respond quite differently to an expert witness. One person's horrendous mutilation may be another person's artistic masterpiece. Which witness is likely to be more objective? Courts will need to provide some guidance on this issue, and indeed this may be the 'yardstick' Adeney was referring to.

It seems likely that an expert witness will need to attest to the meaning or message of the work - its conceptual coherence, or essentially its integrity. The expert witness would then need to explain how the defendant's conduct failed to respect the work/authorship, and how this lack of respect amounts to derogatory treatment. In other words, does the defendant's conduct corrupt or compromise the author's message to the point where authorial harm to honour or reputation occurs? This evidence should certainly not judge the merits of the work, since that would raise questions about judgment standards, and imply that different levels of respect are due to different works. There is a danger that the personal prejudices and subjective views of the expert witness will influence the assessment of prejudice, however perhaps this is simply unavoidable.

162 Davies and Garnett, above n 75, [12-011]; La Société des gens de lettres de France v SA Les Éditions Plon, Cour d'appel de Paris [Paris Court of Appeal], 07/05821, 19 December 2008 reported in (2009) 40 International Review of Intellectual Property and Competition Law 979, 981.

163 Adeney, 'The Moral Right of Integrity: the Past and Future of "Honour"', above n 43, 129 (emphasis added). 
There is also a danger that exclusively considering the evidence of expert witnesses would view the author's work through an excessively rarefied prism, and exclude the broader voice of 'society'. On one hand, claimants should not be required to, for example, lodge expensive survey evidence. Yet, the entire claim should not be resolved by reference to a person plucked at random from a city commuter bus, particularly when his or her fellow passenger may have a completely different view. It seems inevitable that such a person would simply transfer their own personal subjective prejudices to the assessment process.

Much of course also depends on the nature of the work. One should generally be able to locate a suitable expert witness in the broad area of literary, musical, dramatic or artistic works. If the author is especially renowned, it is likely that there will be persons who are familiar with the author's work, and who can refer to any written commentary on the particular work or author. However, if the work is, for example, a personal letter used to market laundry detergent, or in a political campaign, different issues may be raised, and the need for an expert witness reduces.

As suggested above, we must also take care with a test based on concepts of respect, since it may import criteria not intended by Parliament. As mentioned above, the Australian moral right of integrity is not a positive right to respect the work; it is a prohibition on conduct in respect of a work which is prejudicial to the honour or reputation of an author. The Australian right is much narrower than many European models, which give living authors sometimes surprising discretion to restrain what reasonable members of the community may regard as acceptable conduct, or at least conduct which is not prejudicial to honour or reputation. ${ }^{164}$ Conduct causing prejudice to honour or reputation is but one example of a lack of respect for the work. And indeed it is foreseeable that some acts may be done with the greatest of respect, but may nevertheless injure the author's honour or reputation. For example, the author of fan fiction may create their work in almost reverential admiration of a deceased author, but may nevertheless prejudice that author's honour. There is clearly some interpretive room depending on how 'honour' is construed. It is not inconceivable to equate honour with respect, however in the end it must be established that the lack of respect is prejudicial to the author's honour.

Whatever objective measure is used, it must be established that the author's honour is prejudiced. It is not enough that the community be offended. However, Parliament must have accepted that the author would not be in a position to defend their own honour after death. In those circumstances, Adeney's proposal is to regard the community as the author's witness, in effect the custodian of the author's honour. In this respect, this model may be very similar to model 2. In effect, the witness(es) are viewing the defendant's act, assessing its potential to corrupt the author's meaning or message, and concluding that such conduct would have prejudiced the author's honour or reputation.

164 See, eg, Davies and Garnett, above n 75, [12-012]; Winston Maxwell, 'Moral Rights Clauses after Barbelivien' (2004) 15(4) Entertainment Law Review 121, 122: 'Normally, the right to integrity permits the author to object to any change in his or her work. The judge is not supposed to second-guess the author's judgment. If the author objects to a given modification, that is sufficient in itself to constitute a moral rights violation, whether or not the author's position might be considered reasonable' (emphasis in original). 
As mentioned earlier, many of the questions relating to the type of evidence and the identity of the witness necessary to satisfy the objective control in model 1 may also apply in respect of this model 3. Although not strictly a moral rights case, Schott Musik International GMBH \& Co $v$ Colossal Records of Australia Pty Ltd ${ }^{165}$ may provide some guidance. That case concerned the alleged 'debasement' of a musical work under the now repealed s 55(2) of the Act. ${ }^{166}$ The work was Carl Orff's 1936 composition Carmina Burana, renowned for its stirring O Fortuna chorus. In 1996, an Italian group FCB released a 'techno' dance variation of that chorus, popular at 'rave' parties. Schott Musik, the owner of the copyright in Orff's work, argued this was a debasement of Orff's work by altering its quality and integrity and adulterating it. The meaning of debasement had not previously been considered by an Australian court, and for present purposes, nor had the means of proving it. Importantly, the Court clarified that s 55(2) was concerned with the effect of the adaptation on the work and not with the 'honour or reputation' of the author. Thus the evidence at issue was wholly objective, and Orff's death was irrelevant to the question of debasement. However, to the extent that debasement was measured objectively, is Schott Musik instructive?

At first instance, Tamberlin J held that the treatment did not debase the work. This was affirmed on appeal. Tamberlin J noted that debasement:

necessarily involves an evaluation by reference to musical tastes and preferences. What is

debasement to a large section of the community may be an enhancement or an alteration of neutral effect to other representative sections of the community. ${ }^{167}$

He held that s 55(2) was 'silent as to the identity of the arbiter or audience according to whose tastes and discernment the work is to be considered debased', and that it was ultimately for the Court to decide the issue 'on the evidence placed before it'.168 Tamberlin J held that it is necessary to consider a 'broad spectrum of taste and values', 169 and 'the overall impression which [the alleged debasement] is likely to make on a community with a wide range of tastes and attitudes in relation to adaptations and musical forms.' 170

The Court did not specify the required evidence, but noted that:

While some guidance can be obtained from 'expert' witnesses, the question is largely one of impression and the Court must decide on the evidence placed before it whether the adaptation is so extensive, detrimental or inferior, as a whole that it amounts to debasement. ${ }^{171}$

Despite this warning, and the stated need to consider a broad spectrum of taste and values, the evidence placed before the Court was almost exclusively from experts, and included:

- $\quad$ an eminent composer and musician;

165 (1996) 71 FCR 37 (Tamberlin J) ('Schott Musik'), affd (1997) 75 FCR 321 (Wilcox, Hill and Lindgren JJ) ('Schott Musik appeal').

166 Section 55(2) provided that the compulsory licensing provisions of s 55(1) did not apply in relation to a record of an adaptation of a musical work if the adaptation 'debases' the work.

167 Schott Musik (1996) 71 FCR 37, 42.

168 Ibid.

169 Ibid 44.

170 Ibid.

171 Ibid. 
- the Chair of the Musicology Unit of the Sydney Conservatorium of Music, University of Sydney;

- a full-time opera singer;

- a full-time composer of classical music; and

- the operator of a retail record store, who was the only non-expert witness.

Tamberlin J clearly took this evidence into account, preferring Colossal Records' expert witness, thus it is unclear how a 'broad spectrum of taste and values' was considered.

On appeal, Hill J said the test is objective and s 55(2) applies 'where the adaptation has the effect of causing a reasonable person to think less of the original'. ${ }^{172}$ The evidence should not be directed 'to matters of musicology or taste'. ${ }^{173}$ He then held that in his view, a reasonable person would not consider the adaptation a debasement, essentially assuming the position of the reasonable person. Lindgren J also effectively made the determination himself. He could say no more 'than that in my opinion, the answer to the question in the present case is "No"'.174 Wilcox J also seemed to discount the expert evidence. He conceded that 'judges may be forced to consider issues concerning artistic merit and taste', 175 but they are not required 'to become involved in the type of musical analysis undertaken in this case by [the expert witness]'. ${ }^{176}$ Ultimately, Schott Musik does not clearly articulate the evidentiary test for debasement. However, the appeal Court does suggest that the question can be resolved in the absence of expert evidence, and indeed that the court may make that assessment itself. These principles could be usefully applied to an objective consideration of harm to honour, and indeed several of the decisions discussed above and below suggest that, ultimately, notwithstanding lip service being paid to third-party witnesses, the courts make the determination themselves.

\section{Model 4 - presumed prejudice}

As mentioned above, if prejudice to honour can be presumed due to the circumstances of the case, then an integral objective control already exists. There is no evidence to objectively assess. This is likely to be a rare case, and it would be risky for applicants to proceed in the expectation that a court will agree that the defendant's conduct necessarily harms the author's honour. For example, in Tidy, ${ }^{177}$ the author's cartoon series of dinosaurs were used without the author's permission as illustrations in a book published by the museum, during which process the cartoons were reduced to one seventh of their original size, and a background colouring of pink and yellow was added to the black and white drawings. Tidy claimed that this treatment was derogatory ${ }^{178}$ and sought summary judgment. The application was refused. Rattee J rejected the

Tidy argued that the reduction in size resulted in details becoming imperceptible and the captions becoming difficult to read, suggesting that he could not be bothered to redraw the cartoons in a suitable format for the book.

Schott Musik appeal (1997) 75 FCR 321, 332.

Ibid 333.

Ibid 337.

Ibid 324 .

Ibid. 
argument that 'it ought to be so obvious to me just looking at the reproduction in the book that it is a distortion of the plaintiff's work or otherwise prejudicial to his reputation that I ought to give judgment'. 179

In Pasterfield $v$ Denham ${ }^{180}$ the plaintiffs had prepared drawings for inclusion in a tourism brochure, and gave permission for another artist to update them. They argued that the changes constituted derogatory treatment of their work, because various details had been deleted, and all the foreground and background of the picture had been removed and re-drawn, including the truncation of some of the figures depicted as walking on the pavement. They relied on expert evidence that the changes reduced 'the vibrancy and excitement' of the original, left one leaflet appearing unfinished, and did not accurately reflect the plaintiffs' rendering or detail. Overend J criticised the expert witness's evidence as 'seriously flawed', 181 because 'nowhere in his written opinion does he refer to the honour or reputation of the author'. ${ }^{182}$ This suggests not only that the Court requires expert evidence, but that evidence must specifically address prejudice to honour or reputation. This may have been unnecessarily harsh. If the expert witness detailed deleterious modifications, harm to honour or reputation could have been inferred. In reality, the Court simply did not regard the modifications as sufficiently objectionable. Pasterfield demonstrates that expert witnesses must clearly make the link between the impugned conduct and harm to honour or reputation, but even if they do, that expert evidence may not be accepted. In that case, isn't the Court itself ultimately providing the objective control?

In Confetti Records $v$ Warner Music UK Ltd, ${ }^{183}$ the plaintiff claimed that his moral right of integrity in his musical work had been infringed when the defendant overlaid rap words which apparently contained references to violence and drugs. ${ }^{184}$ Contra Perez, 185 Lewison J said in dismissing the claim that:

the fundamental weakness in this part of the case is that I have no evidence about [the author's] honour or reputation. I have no evidence of any prejudice to either of them. [The author]

himself made no complaint about the treatment of 'Burnin' in his witness statement. Mr

Shipley invites me to infer prejudice. Where the author himself makes no complaint, I do

not consider that I should infer prejudice on his behalf. ${ }^{186}$

This appears to mandate two tranches of evidence. First, there must be 'evidence about [the author's] honour or reputation'. ${ }^{187}$ The author's failure to articulate the effect on his honour or reputation of the defendant's conduct was a 'fundamental weakness'. The implication is that the Court required direct evidence from the author, which, as discussed above, clearly has implications in a post-mortem context. Second, there must

179 Tidy (1995) 39 IPR 501, 504.

180 [1999] FSR 168.

181 Ibid 182

182 Ibid.

183 [2003] EWCh 1274 (Ch) (23 May 2003).

184 Which, in the words of the court, 'led to the faintly surreal experience of three gentlemen in horsehair wigs examining the meaning of such phrases as 'mish mish man' and 'shizzle (or sizzle) my nizzle': ibid [151].

185 Perez [2012] FMCA 2 (10 February 2012), which also dealt with a modification of a rap song. 186 Confetti Records v Warner Music UK Ltd [2003] EWCh 1274 (Ch) (23 May 2003) [157] (emphasis added). 
be evidence of prejudice to honour or reputation. The Court does not explain how that evidence should be adduced, although it appeared to expect expert evidence to translate the meaning of the impugned words, which were effectively a foreign language, ${ }^{188}$ or at least ambiguous. ${ }^{189}$ The Court rejected the applicant's assertion that the treatment was derogatory because 'all coherence of the original work has been lost as a result of the superimposition of the rap. ${ }^{190}$ In particular, the Court was not prepared to infer prejudice from the fact that the defendant 'rode the rhythm right through the track'. ${ }^{191}$ Indeed, the only thing the Court was prepared to infer was that the applicant's song was itself designed to be the background track to a rap. ${ }^{192}$ In other words, it was used originally in the same manner that the defendant had used it.

Perez,193 a decision of the Australian Federal Magistrates Court, and the only Australian decision to directly consider the right of integrity, goes further than any of the United Kingdom and Canadian case law in suggesting that prejudice may be presumed in appropriate circumstances. The American resident applicant, Mr Perez, is an internationally-renowned, performing artist known as 'Pitbull' and 'Mr 305'. The respondent, Mr Fernandez, is a Perth DJ and promoter known as 'DJ Suave' who runs the Suave website. In 2008 the parties negotiated an Australian concert tour by Mr Perez, which Mr Fernandez was to have promoted. To promote the tour, Mr Perez provided to Mr Fernandez a recording ('audio drop') of the following words spoken by Mr Perez: 'Mr 305 and I am putting it down with DJ Suave'. The planned tour was subsequently cancelled and resulted in breach of contract litigation and animosity between the parties. In December $2010 \mathrm{Mr}$ Fernandez modified the applicant's song Bon, Bon by deleting the Spanish words 'je, je, je, je, je, mira que tu estas rica'194 at the start of the song and replacing them with the audio drop. He then uploaded a copy of the modified song, and for approximately one month it was streamed whenever any person visited the Suave website. He also played the modified song in the nightclubs where Mr Fernandez worked as a DJ. The Court held that, inter alia, Mr Fernandez breached Mr Perez's moral right of integrity.

It was held that Mr Fernandez's conduct was prejudicial to Mr Perez's honour or reputation in two ways:

i. first, because persons listening to Bon, Bon for the first time through the Suave website, will have presumed that the audio drop formed part of the original work, that Mr Fernandez was a subject of the song, and that Mr Perez had written and performed it about him; ${ }^{195}$ and

193 Perez [2012] FMCA 2 (10 February 2012).

194 Which translates as 'heh, heh, heh, heh, heh, see that you're rich'.

195 Perez [2012] FMCA 2 (10 February 2012) [86]. The court made a similar comment earlier in the judgment: 'I accept ... that the rap/hip hop genre is one in which an artist's commercial and artistic associations really matter. Success in building a reputation, developing a fan base, selling records, attracting people to concerts, and ultimately entering into lucrative commercial sponsorships and endorsements depends in large measure on the other artists and brands the artist is seen to associate with. It is also a genre which has been closely linked 
ii. second, there would be a particular class of listeners who would know the significance of Mr Perez's associations as an artist, have been aware of the failed concert tour and the animosity between the two parties, and would therefore see the modification of the song as a 'ruse' to mock Mr Perez's reputation. 196

As to the first type of prejudice, the Court stated further that:

a) an artist's honour and reputation depends on whom he or she associates with, and is a driver of artistic (and with it commercial) success. The artist goes to great lengths to control whom he or she associates with;

b) given that evidence, the distortion of Mr Perez's work, such as to create a false association, should be regarded as prejudicial to his honour and reputation as an artist per se;

c) that it is in fact prejudicial is made clear by the circumstances of Mr Perez's relationship with Mr Fernandez; it is not necessary for the applicants to lead evidence from members of the public as to the way the work would be received; [and]

d) that the treatment of the work was prejudicial may be presumed. ${ }^{197}$

Of most interest is the Court's preparedness to presume prejudice due to the particular circumstances of the parties' relationship. This is particularly beneficial in the postmortem context, alleviating the LPR's evidentiary burden and correspondingly reducing the cost of litigation. This is, however, a departure from the case law discussed above, is dependent on the existence of peculiar facts from which prejudice can be inferred, and it is unclear whether a superior Australian court would adopt the same approach.

\section{E Model 5 - the reasonableness defence}

In this model, the reasonableness control is provided by the defence that a person does not infringe the right of integrity of authorship if that person establishes that it was reasonable in all the circumstances to subject the work or authorise it to be subjected to the derogatory treatment. ${ }^{198}$

Because 'all the circumstances' can be taken into consideration, this is a very broad defence. In a post-mortem context, it may even permit the defendant to argue that, due to the passage of time, the fact of the author's death, and/or the difficulty in locating the author's LPR, the derogatory treatment was reasonable. In Germany, an overt balancing process between the interests of the author and others is undertaken, and some moral rights claims have failed when the court subordinated the interests of the author's heirs to the defendant's interests in engaging in the impugned conduct, essentially because considerable time had passed since the author's death. ${ }^{199}$ But it must be recalled that the Australian reasonableness defence is only relevant after a finding of infringement. It is somewhat circular and inconsistent to find infringement notwithstanding the author's death, and then to argue that the author's death renders that infringement reasonable.

to 'DJ-ing'. Association between artists and DJs continue to play an important role in promoting and building audiences for rap/hip hop music': at [68]. Ibid [88].

Ibid [98] (emphases added).

Section 195AS(1)

See the cases discussed in Melville B Nimmer and Paul Edward Geller (eds), International Copyright Law and Practice (Matthew Bender, 1993) §7(1)(d), §7(3). 
Under the Act, an inclusive list of factors must be taken into account in determining whether the defendant's conduct was reasonable, including the nature of the work, the purpose for which the work is used, the manner and context in which it is used, and relevant industry practice. There is clearly overlap between all of the models of objective control discussed above, chiefly model 3, and the defence, particularly the focus on the nature of the work. For example, pursuant to model 3, if the defendant's conduct was appropriate, then it should not prejudice authorial honour. It should also follow that the conduct was reasonable in the circumstances. The opposite should also apply; if the defendant's conduct was inappropriate and authorial prejudice is shown, it may be more difficult to establish that it was reasonable.

However, note that the defence focuses on the defendant's use of the work, and the context in which the defendant uses that work, whereas the models discussed above tend to focus on the author's intent and vision when creating the work. Note also that the burden of proof shifts to the defendant to establish reasonable treatment, whereas the claimant has the burden of establishing derogatory treatment. Therefore the same evidence will not necessarily be led by both the applicant and the respondent. Indeed, this may inevitably lead to a battle of expert witnesses, except in the rare case that the court is prepared to infer prejudice. Therefore where the defence is utilised, this would necessarily complicate and increase the cost of litigation. In all, this could lead to a veritable glut of objective controls. That may be a reason to encourage courts to lighten the applicant's evidentiary burden when establishing derogatory treatment, given the safeguard of the defence.

\section{F Conclusions - objective controls}

The myriad different circumstances arising post-mortem necessarily prevent the universal application of a single objective control. Only model 4 overtly accommodates the court supplying the objective control, although instances when a court would be prepared to presume prejudice to honour will be rare. All of the other models rely on some objective corroboration of the author's subjective responses. Absent the court standing in the shoes of a reasonable person, each model requires appropriate witnesses to measure the effect of the defendant's conduct on the work, and to confirm the reasonableness of the claim that the impugned conduct is prejudicial. However, case law is inconsistent on who those witnesses should be, and a number of cases suggest that, in the end, the court supplies the ultimate objective control through its power to accept or reject evidence. It is argued that model 3 is the preferred approach for establishing prejudice to the honour of a deceased author. In this model, the work is 'interpreted' to determine its message. Expert witnesses would need to provide this evidence. The objective control requires establishing whether the defendant's treatment of the work was appropriate. The critical question is by what standard this should be measured. Under this model, society steps in as custodian of the author's honour. This suggests that 'society' should also be the author's witness. However, the above discussion highlights the multifaceted nature of society, comprising sophisticated and unsophisticated, expert and non-expert, and subjective and objective evidence. It is suggested that careful guidelines would need to be provided with respect to the appropriate evidence. As noted, expert evidence would be required to ascertain the authorial message inherent in the work. That expert evidence could also determine whether the defendant's conduct had compromised that message to the extent that the author's honour would be prejudiced. However, to ensure that broader social interests 
in the integrity of the work are respected, that expert would need to be a hybrid of particular expertise in the subject of the author's work, and broader sensitivity to wider social responses to the author's work.

\section{CONCLUSIONS}

The above discussion ventilated a number of compelling, and sometimes confounding, issues pertaining to the post-mortem exercise of the moral right of integrity. It argued that, while an author's death may complicate the post-mortem protection of moral rights, Parliament clearly intended protection to persist after death. It is therefore essential to articulate judicial guidelines, and interpret the legislation, consistent with that parliamentary objective.

Since reputational prejudice may be objectively determined, the article concentrated on the difficult issues in relation to establishing harm to honour post-mortem, and explained the importance of doing so where reputational harm is absent. A number of models for establishing such prejudice were proposed, explained and discussed. Each model has strengths and weaknesses, and applies optimally to particular circumstances for which it is best designed. However, model 3 is potentially the most universally applicable model, has fewer problems than some of the other models, and is likely to impose the lightest evidentiary burden on the deceased author's LPR. It is therefore the preferred model.

A number of objective controls designed to moderate the risk of hypersensitive authorial responses being advanced were then considered. Again, each model has disadvantages and advantages, and cannot apply in all circumstances. Anglo-Australian case law clearly demands an objective control, but does little to clarify what witnesses should supply it. On balance, model 3 is the preferable objective control. Its primary advantage is that, in most cases, the same witnesses will be used to both establish prejudice to authorial honour by evaluating the work and the effect of the defendant's conduct on it, and supply the objective control.

This article has identified and interrogated a number of complex issues which will inevitably arise for consideration during the long term of posthumous protection of moral rights. It has suggested some proposals for debate and reflection, and demonstrated a need for judicial guidance on a number of questions which will ultimately impact on the honour of the dead. 